\title{
SELF-CARE PRACTICES REGARDING PREVENTION OF URINARY TRACT INFECTION AMONG SECONDARY NURSING STUDENTS
}

\author{
Huda Mohep Fathy Mahmoud, Prof. Dr. Gehad Mohamed Abo-Elmatty, Dr. Nahed Abd- \\ Elazeem Abd-Elsalam, Dr. Afaf Abd-Allah Mohamed Mossad \\ Faculty of Nursing, Clinical Instructor, El-Nasr Secondary Nursing School, Port-Said \\ Professor of Family and Community Health Nursing - Faculty of Nursing - Port-Said University, \\ Lecturer- in Family and Community Health Nursing- Faculty of Nursing, Port Said University.
}

\begin{abstract}
BackGround: Adolescents self-care practices and hygienic care are a critical issues that determines the health status of them. This study aimed to assess the preventive self-care practices against urinary tract infection (UTI) among secondary nursing students. A cross sectional descriptive design was adopted. All secondary nursing schools in Port-Said Governorate were the setting. A total of 247 of female nursing students were recruited suing simple random sampling technique. An interviewing Questionnaire sheet was used to assess students' self- care practices regarding prevention of UTI. The results revealed that $72.1 \%$ of girls had poor level of knowledge regarding anatomy and physiology of the urinary system and urinary tract infection. While, less than two-thirds of them had inadequate total practices. The results showed that, strong positive correlation was detected between students' total knowledge score and total practice score. Conclusion: Majority of nursing students scored poor level of knowledge regarding UTIs and its preventive hygienic practices. Recommendations: more attention should be given to establish educational strategies towards improving female students' health awareness in this topic.
\end{abstract}

Key Words: Nursing students, Prevention, Self-care practices, Urinary Tract Infection. 


\section{INTRODUCTION}

Urinary tract infection (UTI) is broadly defined as an infection of the urinary system usually after bacteria overcome the natural defense mechanism of the urinary area, and may include the lower and upper urinary tracts (Sobel and Kaye, 2010). it is common of all in affecting humans throughout their lifespan. It happens in all age group-from neonates to old patients, but it has a particular effect on females of all ages (especially during the teen period) (Donna, 2010).

The secondary nursing education is believed the largest source of nursing graduates, providing about $94 \%$ of the available nursing workforce. More than that, those nurses are very young, ranging from mid-teenage to young adulthood (El-Noshokarty, 2004).Self -care is the development and use of personal health practices and effective ways to deal with problems and stress for increase their own health, preventing or limiting disease, and maintains well-being. These activities are usually tried without other help. However; in spite of its great importance of self -care practices for health maintenance it may be harmful if it is based on wrong knowledge or harmful attitudes (Mazor-Dray., Levy, Schlaeffer et al; 2011).

Community nurses play an extremely important role central to public education on health hygiene and personal development, including the maintenance of best menstrual and self-care practices among female teens. They always come in contact with this capable of being hurt group and therefore, it is necessary for them to have good knowledge as well as becoming role models to this deliquescent group of the society. It this way becomes as a role to secure/make sure of proper education and encouragement of personal cleaning and best self -care practices among female teens in our community (Adika, Ayinde et al., 2013). 


\section{AIM OF STUDY:}

Assess the preventive knowledge and self-care practices against urinary tract infection (UTI) among secondary nursing students.

\section{Research objectives}

1. Assessing secondary nursing student's knowledge regarding urinary tract infections.

2. Identifying self-care practices regarding prevention of urinary tract infection among secondary nursing students.

\section{Research Questions}

To achieve this aim, the following research questions were formulated:

1. What are the levels of secondary nursing student's knowledge regarding urinary tract infection (UTIs) in Port-Said Governorate?

2. What are the preventive self-care practices against urinary tract infection (UTIs) among secondary nursing students in Port-Said Governorate?

\section{SUBJECT AND METHODS:}

\section{Research Design:}

Across sectional descriptive design was adopted in this study; the study was portrayed under the four main designs.

\section{A-Setting:}

This study was conducted at all the secondary technical nursing schools (four schools) which available in Port-Said Governorate. These schools were: Al-Nasr; Al-Amery; Port-Fouad; and AlMabarah secondary technical nursing school.

\section{B- Sample size:}


A total of 247 secondary technical nursing schools students are selected randomly from mentioned settings.

\section{C-Tool for Data Collection:}

"A structured questionnaire sheet" which was developed by the researcher after reviewing and utilizing the most recent and relevant literature as well as similar researches (Sevil., Kevser., Aleattin et al., 2013 \&Al-Kotb., Elbahnasawy., El Nagar et al., 2016), to assess students' practices and knowledge regarding prevention of urinary tract infection. It included three main parts:

\section{Part 1: Socio-demographic Data:-}

This part contained information related to socio- demographic characteristics and medical history of the studied students which composed of multiple choice questions regarding age, residence, mother and father occupation \& educational level, monthly income, number of family member, number of rooms at home and birth order, past history of UTI .

\section{Part 2: Students' knowledge regarding biological health aspect:-}

This part included multiple choice questions for assessing students' knowledge regarding biological health aspect such as anatomical structure of UT, physiological functions of kidneys, ureters, bladder, and urethra \& Urinary Tract Infection such as, definition of UTI, predisposing factors, causes, risk factors, signs and symptoms, complications and Preventive factors.

\section{Part3: Health practices (as reported by students) associated with UTIs. It included two items which were:}

\section{A-General self-care practices (as reported by students):}

It included multiple choices questions concerning hand washing, showering, materials used for showering, Cleaning genital area after elimination, the direction of cleaning genital area, dryness genital area, materials of underwear ......etc.

\section{B- Practices during menstruation (as reported by students):}

It included multiple choices questions concerning type of towels used during menstruation, 
frequency of changing towels, bathing, materials for cleaning perineal area, washing hands, changing underwear, removal of pubic hair and disposal of sanitary pad, ...etc.

\section{Scoring system for assessing the student's knowledge:}

Scoring system was graded according to the items of interviewing questionnaire; the answers of the students were evaluated by using model key answers prepared by the researcher according to the literature. Each correct answer was given (1) score; (0) score was given to incorrect answer \& didn't know. These scores were converted into a percent score. The total score for all questions related to knowledge was calculated according to the number of correct answers which was equal to 28 marks, that represents $100 \%$ and categorized into:

Good when $\geq 60 \%$ of the total score.

Poor when $<60 \%$ of the total score.

\section{Scoring system for assessing the student's general self-care practices stated by them:}

Answers were coded, each healthy practice scored as (1) score and each unhealthy practice scored as (0) score. The total score for students' practices of menstrual hygiene equals 15 marks, which represents $100 \%$. Final practice score was categorized as follows:

Good healthy practice $\geq 60 \%$

Poor healthy Practice $<60 \%$

Scoring system for assessing the student's self-care practices during menstruation stated by them:

Answers were coded, each usually healthy practice scored as (1) score and each sometimes healthy practices scored as (0) score. The total score for students' practices of menstrual hygiene equal 9 marks, which represents $100 \%$. Final practice score was categorized as follows:

Good healthy practice $\geq 60 \%$

Poor healthy Practice $<60 \%$ 
It was ascertained by a jury consisting of five experts in the field of family and community health nursing in order to check the relevance, coverage content, and clarity of the questions and the appropriate modifications were done accordingly.

\section{Pilot Study:}

A pilot study was carried out on $10 \%$ of nursing students. It was done to test the clarity and practicability of the tools. The results obtained from the pilot study and the opinion of expertise helped in modification of the tools. Accordingly, modifications were done and the final form was developed. Those subjects were not included in the main study sample.

\section{Reliability:}

Cronbach's $\alpha$ coefficient was calculated to assess the reliability of the developed tool through their internal consistency.In order to determine the reliability for the tool a pilot study was carried out on (28) of students.

\section{Methods of data collection:}

The study was conducted from the beginning of April 2016 till the end of December 2016. Data was collected through about five days a month to each school. In every day of data collection, the researcher interviewed with about twelve to thirteen (12-13) of nursing students. full explanation about The purpose of the study was given to all students and oral consent to participate in the study was obtained prior to answering the questionnaire sheet.

The researcher knew and determined the suitable time to the students by the managers of each school according to their class schedule.

Data was been collected from the selecting setting by the researcher using the pre constructed tool at the time of the study.

During data collection interviews, each item \& question of data collection sheet was explained by the researcher to the participants of nursing students. The students were allowed to ask any interpretation or explanation. 
The study tool was filled by the students and it was distributed and answered within 20-30 minutes then collected. The questionnaires filled by the nursing students while they were in clinical areas or in the classroom.

The present study consumed about 9 months, two months of them for obtaining the official permissions, pilot study and modifications of the tool. The next four months consumed for data collection while, the last three months for data entry and statistical analysis.

\section{Ethical Consideration:}

The agreement for the participation of the subjects was taken after the aim of the study was explained to them. They were given an opportunity to refuse the participation, and they were assured that the information given would be treated with confidentiality and used for the research purpose only. The aim of the study was explained to the director of each school to take his permission to do this study.

\section{Statistical analysis:}

All collected data were organized, categorized, tabulated and analyzed according to the type of each data.

\section{Statistical analysis of the data:}

Data were collected and entered into a database file. Statistical analyses were performed by using the Statistical Package for Social Science (SPSS), version 10. Data were described by summary tables and figures. Data were presented using proper statistical tests that were used to determine whether there were significant relations.

Qualitative data were described and summarized using numbers and percentage. Comparison between different groups regarding categorical variables was tested using chi-square test, fisher test and MC Nemar test. Reliability of statistics was assessed using Cronbach's ( $\alpha$ ) test.

\section{RESULTS:}

Table (1): revealed that the mean age of the studied nursing students was $17.02 \pm .98$ years, $91.5 \%$ of them ranged between 16-18 years, $76.9 \%$ of them were living in urban areas. It was observed that the proportion of study group in all grades was also close. It was found that $56.7 \%$ of their 
mothers just read and write, while $6.1 \%$ of them had high education, $71.7 \%$ of their mothers were housewives while, only $19 \%$ of their families had insufficient income.

With regarding to the students level of knowledge it reported that that $72.1 \%$ of nursing students had poor knowledge regarding UTIs and anatomical\& physiological aspects of urinary system while, $27.9 \%$ of them had satisfactory total score regarding their total knowledge.

In relation to the nursing students regarding their general self care practices associated with UTI, It reveals that nursing students had good general practices regarding Method used for underwear washing, cleaning the genital area after WC, materials used for hand washing, average of drinking tea or coffee a day, Materials used for bathing, underwear material, , and had adequate practices regarding methods for drying the underwear $(54.7 \%, 56.7 \%, 58.3 \%, 59.1 \%, 64.4 \%, 65.6 \%$, and $70.9 \%$ ) respectively. Also it was noticed that the majority of studied students had inadequate general practices regarding caring of genital area (direction), drying genital area after WC, wearing tight pants and jeans, hand washing after toilet using, frequency of changing their underwear, bathing, and regarding drinking the appropriate amount of water a day 1-3 glasses $(57.1 \%, 61.5 \%, 64.8 \%, 67.6 \%, 72.5 \%, 77.3 \%$, and $86.2 \%)$ respectively.

In regarding to nursing students self-care practices during the menstrual period that associated with UTI it observed that nursing students had good healthy practices during the menstrual period regarding the frequency of taking bath, sanitary pad disposal and using absorbent hygienic pads $(54.3 \%, 61.5 \%$ and $73.7 \%$,) respectively. Also it was noticed that the majority of studied students had inadequate practices during menstrual period regarding removing pubic hair and perineum area, using talcum powder on the perineum, the materials used for genital area cleaning, using scented materials or deodorants on the perineum, washing their hands only after changing the towel and the frequency of changing sanitary pads $(50.2 \%, 55.5 \%, 63.6 \%, 63.6 \%, 66.4 \%$, and $68.8 \%$ ) respectively.

According to the nursing student's total self- care practices regarding prevention of UTI, It reveals that $62.8 \%$ of studied nursing students had inadequate total practices score level regarding prevention of the urinary tract infection while, only $37.2 \%$ of them had adequate score level.

Statistical relationship between students' total levels of knowledge score level and their sociodemographic characteristics was found. Also highly statistically significant relation between 
nursing student's total level of knowledge and their age was found as well as their mother's education.

Regarding statistical relationship between studied nursing students' total healthy practices scores and their socio-demographic characteristics, It shows that there was highly statistical significant relation between nursing student's total healthy practices and student's residence while there was a statistically significant relation between total practices of studied students with their grade and their income.

Statistical correlation between studied nursing students' knowledge and their practices score level was found $\left(\mathrm{r}=173^{* *}\right)$. 
Table (1): Distribution of studied nursing students according to their socio-demographic characteristics $(\mathrm{N}=247)$.

\begin{tabular}{|l|c|c|}
\hline Socio demographic characteristics & Frequency & Percentage \\
\hline Age: & & \\
16- 18 & 226 & $\mathbf{9 1 . 5}$ \\
more than 18 & 21 & $\mathbf{8 . 5}$ \\
Mean \pm SD $=17.02 \pm .98$ & & \\
\hline School: & & $\mathbf{2 5 . 5}$ \\
Al Nasr & 63 & $\mathbf{2 3 . 1}$ \\
Al Amery & 57 & $\mathbf{2 5 . 1}$ \\
Port -Fouad & 62 & $\mathbf{2 6 . 3}$ \\
Al-Mabarah & 65 & $\mathbf{3 3 . 2}$ \\
\hline Student grade: & & $\mathbf{3 2 . 4}$ \\
First grade & 82 & $\mathbf{3 4 . 4}$ \\
Second grade & 80 & $\mathbf{2 3 . 1}$ \\
Third grade & 85 & $\mathbf{7 6 . 9}$ \\
\hline Residence: & 57 & $\mathbf{3 . 2}$ \\
Rural & 190 & $\mathbf{5 6 . 7}$ \\
Urban & & $\mathbf{8 . 9}$ \\
\hline Mother education: & 8 & $\mathbf{2 5 . 1}$ \\
Illiterate & 140 & $\mathbf{6 . 1}$ \\
Read and write & 22 & $\mathbf{7 1 . 7}$ \\
Primary school & 62 & $\mathbf{2 5 . 1}$ \\
Preparatory school & 15 & $\mathbf{3 . 2}$ \\
\hline University & 177 & $\mathbf{4 2 . 5}$ \\
\hline Mother occupation: & 62 & $\mathbf{1 9 . 0}$ \\
\hline House wife & 85 & \\
Employee & 47 & \\
Others & & \\
\hline Family income: & & \\
Enough and saving & & \\
Enough & & \\
Not enough & & \\
\hline
\end{tabular}

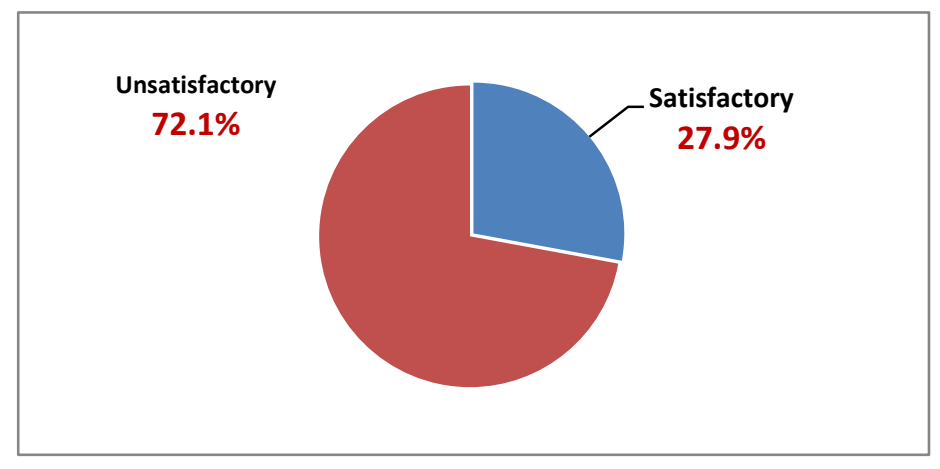

Figure(1): Distribution of studied nursing students regarding their total knowledge about urinary system and UTI $(n=247)$. 
Table(2): Distribution of studied nursing students regarding their general self care practices

\begin{tabular}{|c|c|c|c|c|}
\hline \multirow{2}{*}{ General self care practices } & \multicolumn{2}{|c|}{ Adequate } & \multicolumn{2}{|c|}{ Inadequate } \\
\hline & No & $\%$ & No & $\%$ \\
\hline Bathing & 56 & 22.7 & 191 & 77.3 \\
\hline Used Healthy Materials for bathing & 159 & 64.4 & 88 & 35.6 \\
\hline Clean the genital area after using the toilet each time & 140 & 56.7 & 107 & 43.3 \\
\hline Direction of wiping the genital area & 106 & 42.9 & 141 & 57.1 \\
\hline Drying genital area after using toilet each time & 95 & 38.5 & 152 & 61.5 \\
\hline Changing underwear's daily & 109 & 44.1 & 138 & 55.9 \\
\hline Frequency of changing underwear & 68 & 27.5 & 179 & 72.5 \\
\hline Used Healthy Underwear material & 162 & 65.6 & 85 & 34.4 \\
\hline used Healthy Method for underwear washing & 135 & 54.7 & 112 & 45.3 \\
\hline used Healthy Methods for drying the underwear & 175 & 70.9 & 72 & 29.1 \\
\hline Wash hands after using the toilet & 80 & 32.4 & 167 & 67.6 \\
\hline used Healthy Materials used for washing hands & 144 & 58.3 & 103 & 41.7 \\
\hline drink enough water daily & 34 & 13.8 & 213 & 86.2 \\
\hline Daily drink (tea- coffee) & 146 & 59.1 & 101 & 40.9 \\
\hline Wear tight pants and jeans & 87 & 35.2 & 160 & 64.8 \\
\hline
\end{tabular}


Table(3): Distribution of studied nursing students regarding their self-care practices during the menstrual period that associated with UTI $(\mathrm{N}=247)$.

\begin{tabular}{|c|c|c|c|c|}
\hline \multirow{2}{*}{ Self-care practices during the menstrual period } & \multicolumn{2}{|c|}{ Adequate } & \multicolumn{2}{|c|}{ Inadequate } \\
\hline & No & $\%$ & No & $\%$ \\
\hline Using as sanitary pad during the menstrual period & 182 & 73.7 & 65 & 26.3 \\
\hline Frequently of changing sanitary pads & 77 & 31.2 & 170 & 68.8 \\
\hline Taking a bath during the menstrual period & 134 & 54.3 & 113 & 45.7 \\
\hline Materials used for genital area cleaning & 90 & 36.4 & 157 & 63.6 \\
\hline Using scented materials or deodorants on the perineum & 90 & 36.4 & 157 & 63.6 \\
\hline Using talcum powder on the perineum & 110 & 44.5 & 137 & $\mathbf{5 5 . 5}$ \\
\hline Hand washing regarding changing of pads & 83 & 33.6 & 164 & 66.4 \\
\hline Removing pubic hair regularly each month & 123 & 49.8 & 124 & 50.2 \\
\hline Disposal of used sanitary pads & 152 & 61.5 & 95 & 38.5 \\
\hline
\end{tabular}




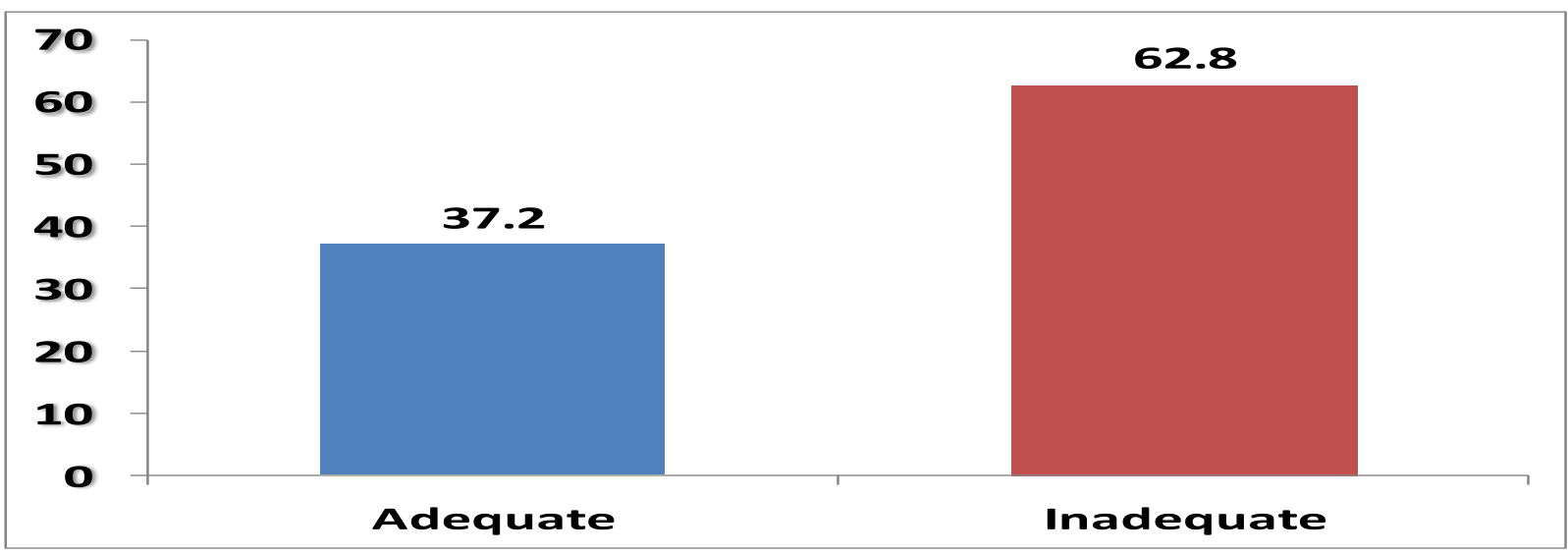

Figure (2): Distribution of studied nursing students regarding their total self- care practices regarding prevention of UTI. ( $\mathrm{N}=247)$. 
Table (4): Statistical relation between studied nursing students' total knowledge score level and their socio-demographic characteristics.

\begin{tabular}{|c|c|c|c|c|c|c|}
\hline \multirow[t]{3}{*}{ Items } & \multicolumn{4}{|c|}{$\begin{array}{c}\text { Nurses knowledge } \\
\end{array}$} & \multirow{3}{*}{$\mathbf{X}^{2}$} & \multirow{3}{*}{ p-value } \\
\hline & \multicolumn{2}{|c|}{ Unsatisfactory } & \multicolumn{2}{|c|}{ Satisfactory } & & \\
\hline & No & $\%$ & No & $\%$ & & \\
\hline \multicolumn{5}{|l|}{ Age: } & \multirow{3}{*}{ McNemar } & \multirow{3}{*}{$.000 * *$} \\
\hline 16- 18 & 161 & 90.4 & 65 & 94.2 & & \\
\hline More than 18 & 17 & 9.6 & 4 & 5.8 & & \\
\hline \multicolumn{5}{|l|}{ School } & \multirow{5}{*}{5.127} & \multirow{5}{*}{$.053^{*}$} \\
\hline Al Nasr & 50 & 28.1 & 13 & 18.8 & & \\
\hline Al Amery & 37 & 20.8 & 20 & 29.0 & & \\
\hline Port Fouad & 48 & 27.0 & 14 & 20.3 & & \\
\hline Al Mabarah & 43 & 24.2 & 22 & 31.9 & & \\
\hline \multicolumn{5}{|l|}{ Student grade: } & \multirow{4}{*}{2.46} & \multirow{4}{*}{.291} \\
\hline First grade & 62 & 34.8 & 20 & 29.0 & & \\
\hline Second grade & 60 & 33.7 & 20 & 29.0 & & \\
\hline Third grade & 56 & 31.5 & 29 & 42.0 & & \\
\hline \multicolumn{5}{|l|}{ Residence: } & \multirow{4}{*}{ Fisher=.614 } & \multirow{4}{*}{.320} \\
\hline Rural & 43 & 24.2 & 14 & 20.3 & & \\
\hline Urban & 135 & 75.8 & 55 & 79.7 & & \\
\hline \multicolumn{5}{|l|}{ Mother education: } & & \\
\hline Illiterate & 4 & 2.2 & 4 & 5.8 & \multirow{6}{*}{6.98} & \multirow{6}{*}{$059^{*}$. } \\
\hline Read and write & 99 & 55.6 & 41 & 59.4 & & \\
\hline Primary school & 13 & 7.3 & 9 & 13.1 & & \\
\hline Preparatory school & 49 & 27.5 & 13 & 18.8 & & \\
\hline University & 13 & 7.3 & 2 & 2.9 & & \\
\hline \multicolumn{5}{|l|}{ Mother occupation } & & \\
\hline House wife & 126 & 70.8 & 51 & 73.9 & \multirow{4}{*}{.242} & \multirow{4}{*}{.886} \\
\hline Employee & 46 & 25.8 & 16 & 23.2 & & \\
\hline Others & 6 & 3.4 & 2 & 2.9 & & \\
\hline \multicolumn{5}{|l|}{ Income: } & & \\
\hline Enough and saving & 79 & 44.4 & 26 & 37.7 & \multirow{4}{*}{2.12} & \multirow{4}{*}{.346} \\
\hline Enough & 69 & 38.8 & 26 & 37.7 & & \\
\hline Not enough & 30 & 16.9 & 17 & 24.6 & & \\
\hline Total & 178 & 100.0 & 69 & 100.0 & & \\
\hline
\end{tabular}


Table (5): Statistical relation between studied nursing students' total practices scores level and their socio-demographic characteristics

\begin{tabular}{|c|c|c|c|c|c|c|}
\hline \multirow[t]{3}{*}{ Items } & \multicolumn{4}{|c|}{ Nurses practice } & \multirow{3}{*}{$\mathbf{X}^{2}$} & \multirow{3}{*}{ p-value } \\
\hline & \multicolumn{2}{|c|}{ Inadequate } & \multicolumn{2}{|c|}{ Adequate } & & \\
\hline & No & $\%$ & No & $\%$ & & \\
\hline \multicolumn{5}{|l|}{ Age } & \multirow{3}{*}{ Fisher $=.384$} & \multirow{3}{*}{.213} \\
\hline 16- 18 & 144 & 92.9 & 82 & 89.1 & & \\
\hline More than 18 & 11 & 7.1 & 10 & 10.9 & & \\
\hline \multicolumn{5}{|l|}{ School } & \multirow{5}{*}{6.54} & \multirow{5}{*}{.088} \\
\hline Al Nasr & 36 & 23.2 & 27 & 29.3 & & \\
\hline Al Amery & 30 & 19.4 & 27 & 29.3 & & \\
\hline Port Fouad & 42 & 27.1 & 20 & 21.7 & & \\
\hline Al Mabarah & 47 & 30.3 & 18 & 19.6 & & \\
\hline \multicolumn{5}{|l|}{ Student grade } & \multirow{4}{*}{6.69} & \multirow{4}{*}{$.035 *$} \\
\hline First grade & 56 & 36.1 & 26 & 28.3 & & \\
\hline Second grade & 55 & 35.5 & 25 & 27.2 & & \\
\hline Third grade & 44 & 28.4 & 41 & 44.6 & & \\
\hline \multicolumn{5}{|l|}{ Residence } & \multirow{3}{*}{ McNemar } & \multirow{3}{*}{$.000 * *$} \\
\hline rural & 36 & 23.2 & 21 & 22.8 & & \\
\hline urban & 119 & 76.8 & 71 & 77.2 & & \\
\hline \multicolumn{5}{|l|}{ Mother education } & \multirow{6}{*}{6.25} & \\
\hline Illiterate & 4 & 2.6 & 4 & 4.3 & & \multirow{5}{*}{.181} \\
\hline Read and write & 95 & 61.3 & 45 & 48.9 & & \\
\hline Primary school & 13 & 8.4 & 9 & 9.8 & & \\
\hline Preparatory school & 32 & 20.6 & 30 & 32.6 & & \\
\hline University & 11 & 7.1 & 4 & 4.3 & & \\
\hline \multicolumn{5}{|l|}{ Mother occupation } & \multirow{4}{*}{1.55} & \multirow{4}{*}{.459} \\
\hline house wife & 107 & 69.0 & 70 & 76.1 & & \\
\hline employee & 43 & 27.7 & 19 & 20.7 & & \\
\hline others & 5 & 3.2 & 3 & 3.3 & & \\
\hline \multicolumn{5}{|l|}{ Income } & \multirow{5}{*}{5.43} & \\
\hline enough and saving & 72 & 46.5 & 33 & 35.9 & & \multirow{4}{*}{$.056^{*}$} \\
\hline enough & 51 & 32.9 & 44 & 47.8 & & \\
\hline not enough & 32 & 20.6 & 15 & 16.3 & & \\
\hline Total & 155 & 100.0 & 92 & 100.0 & & \\
\hline
\end{tabular}

Not Significant $\mathrm{P}>0.05 \quad$ Highly Significant $\mathrm{P} \leq 0.001 \quad$ Significant $\mathrm{P} \leq 0.05$ 
(Table 6): Statistical correlation between studied nursing students' knowledge and practices score level.

\begin{tabular}{|l|l|l|}
\hline Items & \multicolumn{2}{|l|}{ Total knowledge } \\
\hline Total practices & Pearson Correlation (r) &. $\mathbf{1 7 3}^{* * *}$ \\
\cline { 2 - 3 } & Sig. & $\mathbf{. 0 0 6}$ \\
\hline
\end{tabular}

** Correlation is significant at the 0.01 level.

\section{DISCUSSION:-}

The current study revealed that less than three- quarters of studied nursing students had unsatisfactory level of their total knowledge. Also, the present study findings revealed serious deficiencies in nursing student's knowledge regarding most of the studied items related to UTI These findings were in agreement with (Arundathi et al., 2016\& Al-Kotb et al., 2016) who revealed that most of the adolescent students had inadequate knowledge regarding UTI. This may be attributed to insufficient basic information gained from their study about this topic. Also, this may be due to the minor role that educational curriculum played in covering this area of knowledge (Anatomy and Physiology). Lack of knowledge may be due to the fact that student' mothers themselves suffer from lack of information about this topic related to low educational level. In addition, study by (Van Eijk, 2016) mentioned that Lack of adequate knowledge may lead to various urinary diseases among adolescent girls, thus the adolescent nursing students are high risk for developing UTI as mentioned.

Concerning student's general self-care practices this study noticed that most of the nursing students had inadequate general self-care practices score level. Also the current study revealed that more than half of them had inadequate practices related the direction of wiping the genital area after WC. This finding is in agreement with (Vyas et al., 2011; Moustafa and Makloof, 2012\& Al-Kotb et al., 2016) who reported that the majority of students were using incorrect washing and wiping technique to wash genitals of who had a symptomatic genitourinary tract infection. However, on the contrary to the current study and the previous reports, the study by (Sevil et al., 2013) found more than two-thirds of studied students used front to backward 
approach for the genital area cleaning. This result of the current study may be due to the insufficient knowledge and lack of awareness about hygienic and routinely practices that negatively effect on their practice level.

Regarding drying the genital area after WC, Our finding is revealed that more than half of studied nursing Students had inadequate practices. The results agree with (Ahmed \& Khresheh, 2008) in a study in Indian, which reported that majority of girls were using incorrect washing and wiping technique to wash genitals of which most had a symptomatic genitourinary tract infection. And also don't wash Genital region in correct direction.

The current study revealed that around two-thirds of studied students were using cotton under wears material. This result agrees with (Hussein et als, 2014 )who reported that in the study conducted in Arbil .The students whose wear cotton under wear in urban were (40.7\%) and $(55.6 \%)$ in rural area (Haque et al, 2014) in a study about adolescent girls in Bangladesh who mentioned that only $16.8 \%$ of girls used Sanitary pads and. The remainder used poor quality cloths dyed with toxic pigments, which might make them susceptible to uterine pain. The girls also dry the cloths inside the house, which also might have effects. Good hygiene, such as the use of sanitary pads and adequate washing of the genital area, is essential during menstruation.

Concerning changing the underwear, the current study revealed that only less than half of studied nursing students were changing their underwear's daily. This result agrees with (Fakhria et al, 2017) in a study in Iraq Who found that shows that high rate of females ( $82.40 \%)$ used tight under-wear, however majority of female student change their underwear frequently but the of rate of occurrence was high (93.2\%) (Also, (Ozkan and Demir, 2002) reported that women who replaced their innerwear less often were more likely to experience getting infections than those who replaced it more often. Also (Oner et al., 2002) said that changing the underwear often is critical in preventing urinary infections and the underwear may be changed even many times throughout the day especially during the period of intensive discharge.

Although nursing students are well aware of the disinfecting effect of sunlight on clothes but still more than one-quarter of girls were not drying their inner wears in direct sunlight. In contrast to the current study, it has been reported by (Vyas et als; 2015) that less than three quarters of nursing students were not drying their inner wears in direct sunlight. This may be due to different fears among the girls in putting their innerwear outside. 
The current study showed that the majority of studied nursing students had not enough practices related to drinking the appropriate amount of water a day (1-3 glass. This result agrees with (Srivastava,2018) who reported that $40 \%$ of the adolescent girls drank less than four glasses of water a day. Low amount of intake of water not only concentrates urine but also leads to urinary stasis which favors bacterial growth. The reason referred to drinking less to avoid the need of urinating during work classroom or hospital based training sessions and may raise the risk of developing UTI.

Concerning self care practices during the menstrual period, the present study noticed that more than three quarter of the studied students had inadequate self care practices score level. Likewise to the current study, it has been reported by (Adika et al., 2013\&Mohamed and Diab, 2015) that there was inadequate level of self- care practices among adolescents during menstruation. This result may be due to the insufficient knowledge and lack of awareness about hygienic and routinely practices that negatively effect on their practice level. In addition, (Adika et al., 2011) mentioned that optimal care of menstrual hygiene is synonymous with good hygiene practices and inevitably to a healthy living in an adolescent girl`s life.

The current study noticed that less than three quarters of nursing students were using sanitary pads during menstruation. Several studies as (Sheela Pavithran.,2014 \&Palas, 2013) was in the same line with this study and supported this result by reporting that the majority of students were using pads during menstruation. The current study indicated that more than two- thirds of the studied students had inadequate practices regarding frequency of changing sanitary pads. Several studies as (Indhumol et al, 2014 and Jahanbin et al, 2015) are in agreement with this study and reported that higher number of participants changed pads less frequently than needed.

The findings of the current study noticed that more than half of nursing students had adequate practice regarding frequency of taking bath, less than two thirds of them used wrong materials for genital area cleaning, about two-thirds of them had inadequate practices by using scented materials or deodorants on the perineum and less than two thirds of nursing students had adequate practices regarding disposal of sanitary pads. The study by (Sevil et al., 2013) is slightly better in comparison with the results of the current study and found that the majority of the students bathe during menstruation and more than half of students used 'perfume' for malodor during menstruation. Also, (Haque et al., 2014) was in agreement with the current study and revealed that about half of students used soap and shampoo for genital area cleaning and more than half of students disposed sanitary pads by correct manner. 
Avoiding bathing during menstruation due to misbelieve and other cultural rationale is a common erroneous misconception. In the study by (Özdemir et al., 2012), abnormal vaginal discharge was described by a significantly higher proportion of students who strictly avoided bathing during menstruation. Also, (Czerwinski, $2000 \&$ Temel and Metinoğlu, 2007) reported that during this period of increased risk of infection, bathing is highly important in preventing infections and achieving physical and physiological relief.

In the current study about half of nursing students had inadequate practices regarding removing pubic hair regularly each month. In contrast to the current study, (Adika et al., 2013) revealed that more than two third of the adolescent girls are shaving pubic hair and perineum area monthly. These might be attributed to the fact that mothers were shame to speak to their adolescents about this topic and may be also due to lack of proper health education programs in the school.

Results of this study revealed that there is a statistical significant relation between studied student's total knowledge with their age and mother's education while there is no statistically significant relation between student's total knowledge with their grade, residence, mother occupation, and income. The study by (Reid and Bruce, 2003) was in agreement with the current study and established mothers as the most important individuals to educate their daughters on the aspects of genital area and menstrual hygiene. Higher levels of maternal education are therefore important. However, the study by (Mohamed et al., 2012) did not identify any relationship between the maternal education and level of knowledge. This may be explained by the limited number of the students whose mothers had high levels of education in this study.

This findings also agree with (El-kazaz, 2011) who mentioned that there is no statistically significant relation between studied nurses' knowledge with their grade, residence, mother occupation, and their income. Also, (Anusree et al., 2014) indicated that there is no statistically significant relation between studied nursing knowledge with their grade. Also, (Yildırım, 2009) disagrees with the current study and found that there is a statistical relationship between students' total knowledge with student's income. And the latter study reported that women with good monthly income had higher mean scores from the genital hygiene questionnaire by investigating the effects of income level on the knowledge. 
Concerning statistical relationship between student's total practice score level and their sociodemographic characteristics, the findings showed that there was statistical significant relation between students' total practice score level and their grade while, (Adika et al., 2013) found that there was No statistical significant relation between students' total practice score level and their grade. Also, findings showed that there was a highly statistical significant relation between students' total practice score level and their residence. This finding is in agreement with (Slave et al., 2012), who found that there was a statistical significant relation between hygienic practices among adolescent girls and their residence. This may be due to increasing of awareness in urban areas as compared to the rural areas.

Findings also, revealed that there was statistical significant relation between student's total practice score level and their income. Consistent with the current study, (Dan et al., 2002\& Sevil et al., 2013) found that there was statistical a significant relation between hygienic practices among adolescent girls and their income and reported that genital infections were significantly less common among the students whose families had good levels of income. Better income makes it easier to meet hygiene requirements and helps women to conveniently utilize healthcare institutions if they experience any problems with their health.

In addition, the present study showed that there was no statistical significant relation between students' total practice s level and their mother's education \& occupation. Likewise (Mohamed et al., 2012) found no statistical significant relation between students' total practice level and their mother's occupation. While, (Busari, 2012) found that there was statistically significant relation between students' hygienic practices and level of their mother education. This might be because of changing trends in lifestyle.

The study findings revealed that there was strong statistically significant positive correlation between having satisfactory knowledge and adequate practices. This result is in agreement with (Mohamed et al., 2012) who found positive correlation between having the satisfactory knowledge and healthy practices. Also consistent with (Bobhate and Shrivastava, 2011) who mentioned that positive association was observed between having good, fair knowledge and good practice regarding menstrual health. This may be due to the fact that when knowledge improves practice tends to be healthier. 


\section{CONCLUSION:}

According to the results of the present study, some important factors could be concluded:

The majority of the female students score level of knowledge was proved to be poor; less than two-thirds of them had inadequate total practices, majority of them had poor general self-care practices while, more than two thirds of them had poor practices regarding menses. Also the findings revealed that there was a highly statistical significant relationship between the nursing students' knowledge with their total general self-care practice \& total practice regarding menses. Thus as when knowledge improves, practice tends to be more healthy (hygienic). Furthermore, the majority of them have poor score of healthy practices regarding prevention of UTIs, especially which they all were single and young so they are vulnerable to future complications of UTIs.

\section{RECOMMENDATIONS:}

Use of appropriate educational strategies to increase students' health awareness and significance of adopting healthful life style, nutrition \& hygiene, such as organize scientific seminars, group discussion, booklets, and brochures.

All mothers need to be educated regarding menstruation and menstruation-related hygiene practices so that they can break the social inhibitions and empower adolescent young girls with proper knowledge.

Further researches should be conducted to cover other schools, areas and as well from different geographical areas in Egypt in terms of knowledge, attitudes and practice on menstrual hygiene.

\section{REFERENCES:-}

Ahmed.N.M,\& Khresheh .R.M (2016): Impact Of Instructional Program About Prevention Of UTI Recurrence On The Level Of Knowledge And Self-Care Behaviors Among Women With UTI In Saudi Arabia. IOSR Journal of Nursing and Health Science (IOSR-JNHS) e-ISSN: 2320-1959.p- ISSN: 2320-1940 Volume 5, Issue 3 Ver. III (May. - Jun. 2016), PP 43-51 
Adika V. O., Ayinde M. O. and Jack-Ide I. O (2013): Self Care Practices of Menstrual Hygiene among Adolescents School Going Girls in Amassoma Community, Bayelsa State. Academic Journals; 5(5): 99-105.

Adika V.O., Yagba J., Apiyanteide A.F., Ologidi P.W., \& Ekpo K.E. (2011): Perception and Behavior on Use of Sanitary Pads during Menstruation among Adolescent School Girls in Bayelsa State, Nigeria. Adv. Appl. Sci. Res. 2(6):9-15.

Al-Kotb H., Elbahnasawy HT., El Nagar SA.\& Ghabyen NS. (2016): Prevention for Genitourinary Tract Infection among Female Adolescents Students. IOSR Journal of Nursing and Health Science (IOSR-JNHS). 5 (4): 12-18.

Anusree P. C., Ardra Roy, Aswathy B., et al., (2014): Knowledge Regarding Menstrual Hygiene among Adolescent Girls in Selected School, Mangalore with a View to Develop an Information Booklet. IOSR Journal of Nursing and Health Science, e-ISSN: 23201959.p- ISSN: 2320-1940 Volume 3, Issue 1 Ver. IV (Jan. 2014), PP 55-60 www.iosrjournals.org

Arundathi S., Radhika M., Padma, K. Bhanu M.S. \& Indira. S. (2016): A Study to Assess the Effectiveness of Self Instructional Module Regarding Prevention of Urinary Tract Infection among Adolescent Girls in Selected Colleges at Nellore. Imperial Journal of Interdisciplinary Research (IJIR) 2(6): 2454-1362.

Bobhate P. and Shrivastava S. (2011): Across Sectional Study of Knowledge \& Practices about Reproductive Health among Female Adolescents In urban Mumbai, Journal of Family \& Reproductive Health; 5(4) :123.

Busari A. (2012): Menstrual Knowledge \& Health Care Behavior among Adolescent Girls in Rural Nigeria. International Journal of Applied Science and Technology; 2(4):150-153.

Czerwinski B.S. (2000): Variation in Feminine Hygiene Practices - As a Function of Age. Obstet Gynecol Neonatal Nurse Journal 29: 625-633.

Dan M, Pooch F, Levin D (2002): High Rate of Vaginal Infections Caused By Non-C. Albicans Candida Species among Asemptomatic Women. Med Mycol 40: 383-386. 
Dobson A. (1984): Calculating Sample Size, Trans Menziez Foundation 75- 79.

Donna.R.I. (2010): Text Book of Medical Surgical Nursing, $5^{\text {th }}$ edition, Elsevier publications, PP: $552-61$.

El-Kazaz, R.H. (2011): Impact of Implementing Infection Control Program for Nurses to Control Nosocomial Infection in Neonatal Intensive Care Units in Port-Said. Doctorate Thesis, Faculty of Nursing, Port-Said University, Egypt.

El-Noshokarty, A. (2004): The Job of Mercy .Al-Ahram Weekly.Http://Weekly.Ahra.Org/Eg/Print/2004/690/Fe2.Htm.

Fakhria J. M, Salma K. J., Haydaite A. (2017): Prevalence and associated factors of Urinary Tract Infection among female students in University of Babylon, Iraq. Research J. Pharm. and Tech. 2017; 10(6): 1976-1982. DOI: 10.5958/0974-360X.2017.00346.8

Hacıalioğlu N., Nazik E., Kılıç M.A. (2009): A descriptive Study of Douching Practices in Turkish Women. INS j Nurse Prac 15: 57-64.

Haque SE, Rahman M, Itsuko K, et al. (2014): The effect of a school-based educational intervention on menstrual health: an intervention study among adolescent girls in Bangladesh. BMJ Open2014; 4: e 004607. doi:10.1136/bmjopen-2013-004607.

Hussein. K.H ; Palpitany. S.A Ahmed. S.H(2014): Prevalence of Urinary Tract Infection among Secondary School Students in Urban and Rural in Erbil: Comparative Study. Kufa Journal For Nursing Science Vol.4 No. 32014

Indhumol, T., S. Pavithran, and George. L.K. (2014): Effectiveness Of Structured Teaching Program On Knowledge Regarding Prevention Of Urinary Tract Infection Among Adolescent Girls. International Journal of Pharma Medicine and Biological Sciences, 2014. 3(3): p. 121

Jahanbin, I., Heydari, N.,Ghodsbin ,F\& Sayadi.,M(2015): The Effect of Peer-Education on UTIRelated Preventive Behavior According to HBM among First-Grade High School Female Students in Shiraz, 2014. Journal of health sciences and surveillance system, 3(1): p. 20-26. 
Koştu N. \& Beydağ K. (2009): Genital Hygiene Behaviors of Women Who Applied to the Gynecology Policlinic Ataturk University, School of Nursing Derg 12: 1.

Mazor-Dray E., Levy A., Schlaeffer F., Sheiner E. (2011): Maternal Urinary Tract Infection: Is it Independently Associated with Adverse Pregnancy Outcome? J Maternal Fetal Neonatal Med. Feb; 22(2):124-8.

Mohamed N. H. \& DiabS. (2015): Menstrual Disorders and Hygienic Self Care Practices among Adolescent Girls in Preparatory year at Al-Jouf University. IOSR Journal of Nursing and Health Science (IOSR-JNHS) 4, (3): 46-54.

Mohamed AH., El-Beih A., Abd El- Moniem A. D.,\&Abd- El Aal A.E. (2012): Health Practices among Female University Students Regarding Prevention of Reproductive Tract Infections. Journal of Applied Science and Technology; 2(4):150-153.

Moustafa M.F., Makloof E.M. (2012): Association Between the Hygienic Practices for Genital Organs \& Sexual Activity on Urinary Tract Infection in Pregnant Women at Women's Health Centre at Assiut University Hospital, Journal of American Science. 8(9):515-22.

Naire M.K., Bhave S.Y. (2002): Teenage Care. Indian Academy of Peadiatric Guide book. Brookers publishing company.PP:22-46.

Öner S., Demirhindi H., Sütoluk Z., and Akbaba M. (2002): A genital Infection Was Born in the City Health Clinic, 8 National Public Health Congress Abstract Book, Diyarbakır PP: 322-326.

Özdemir S., Ortabağ T., Tosun B., Özdemir Ö., Bebiş H. (2012): Evaluation of Knowledge and Behaviors of Knowledge about Genital Hygiene of Nursing School Students. Gülhane Medical Journal 54: 120-128. 
Özkan S. \& Demir Ü. (2002): To Determine the Efficacy of the Nurse in Diagnosing Vaginitis in 15-49 Year Old Women and to Investigate the Causes of Vaginitis. Health and Society 4: 54-61.

Palas P. (2013): The Impact of Women's Detention in Genital Hygiene Practices. Anadolu Nursing and Health Sciences Journal 16(1): 1566 -1099.

Reid G, Bruce AW (2003): Urogenital Infections in Women: can Probiotics Help? Postgrad Med J 79: 428-432.

Sevil S., Kevser O., Aleattin U., Dilek A., and Tijen N. (2013): An Evaluation of the Relationship between Genital Hygiene Practices, Genital Infection. Gyne \& Obstet Journal, p.p. $3: 187$

Slave S., Dase R., Mahjan, S., and Adchitre S. (2012): Assessment of Knowledge \& Practices about Menstrual Hygiene amongst Rural \& Urban Adolescent Girls. A comparative Study, International Journal of Recent Trends in Science \& Technology.3 (3):65-70.

Srivastava,S (2018): Analytical study of urinary tract infection in adolescent girls. International Journal of Reproduction, Contraception, Obstetrics and Gynecology Srivastava S. Int J Reprod Contracept Obstet Gynecol. 2018 Apr;7(4):1385-1388 www.ijrcog.org pISSN 2320-1770 | eISSN 2320-1789

Sobel JD, Kaye D (2010): Urinary Tract Infections. In: Principles and Practice of Infectious Disease. 7. Elsevier; PA, USA: Pp: 957-985.

Temel M., and Metinoğlu M. (2007): Tekirdağ İline Bağlı 1 ve 4 nolu sağlık ocaklarına başvuran 15- 49 yaş kadınlarda genital hijyen uygulamalarının incelenmesi. İ.Ü.F.N. Hemşirelik Derg 15: 91-99.

Van Eijk A.M. (2016): Menstrual Hygiene Management among Adolescent Girls in India: A Systematic Review and Meta-Analysis. BMJ open, 6(3): 10290.

Vyas S., Varshney D., Sharma P., Juyal R ., Nautiyal V., and Shrotriya V.P. (2015): An Overview of the Predictors of Symptomatic Urinary Tract Infection Among Nursing Students._Annals of Medical and Health Sciences Research, 5(1): 54-58. 
Vyas S., Sharma P., Srivastava K., Nautiyal V., and Shrotriya V.P. (2011): Role of Behavioral Risk Factors in Symptoms Related to UTI Among Nursing Students. Tertiary care Hospital of North India from Aug 2011-Oct 2011, Annals of Medical and Health Sciences Research.

Yildırım F. (2009): Genital Hygiene Behaviors and Related Factors in Women Living in Rural and Urban Areas. Master Thesis. Selcuk University, Konya.P.63.

\title{
الرعاية الأتية المتعلقه بالوقاية من عدوي المسالك ممارسات
}

\section{البولية بين طالبات التمريض الثانوى}

\begin{abstract}
هدي محب فتحي محمود، أ.د / جهاد محمد ابو المعاطي، د/ ناهد عبد العظيم عبد السلام،د/ عفاف عبد الله محمد مسعد اخصائية تصريض بددرسة النصر الثانوبة الفنبة للتهريض بيورسعبي . استاذ تصريض صحة الأسرة والمجتمع -كلبة التهريضجامعة بورسعبد ، مدرس تمريض صحة الأسرة والمجتع ـكلية التمريض-جامعة بورسعيد.
\end{abstract}

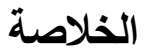

تعتبر ممار اسات الرعاية الذاتية مسالة حيوية تحدد الحالة الصحية للمر اهقيين وتؤثر ايضا فى ممارساتهم الصحية في فترة البلوغ.. إن هدف الدراسة هو تقييم همارسات الرعاية الذاتية المتعلقه بالوقاية من عدوي المسالك البولية بين طالبات التمريض الثانوى فى محافظة بورسعيد.الدراسة وصفية، وأجريت الدراسة فى جميع المدارس الثانوية للتمريض ببورسعيد حيث شملت العينة 247 طالبة أختيرت عشو ائيا. نم جمع البيانات بإستخدام إستمارة إستبيان لتقييم ممارسات الرعاية الذاتية المتعلقة بالوقاية من عدوى المسالك البولية. خلصت نتائج الدراسة إلى أن أغلبية الطالبات (72.1\%) ليس لديهن المعلومات الكافية والمتعلقة بهذا الموضوع بينما أقل من ثلثان عدد الطالبات (62.8.8\%) ليس لديهن الممارسات الصحية و الكافية المتعلقة بالوقاية من عدوى المسالك البولية. أظهرت النتائج وجود علاقة ذات دلالة إحصائية بين المعرفة الكلية للطالبات، وبين النتيجة الكلية لممارسات الرعاية الذاتية المتعلقة بالوقاية من عدوى المسالك البولية.استتتجت الاراسة أن لدى غالبية الطالبات مستوى غير مقبول من المعرفة حول عدوى المسالك البولية والوقاية منها، وبالتالى كانت الممارسات الصحية الغير السليمة فيما يتعلق بالوقاية من التهاب المساللك البولية سائدة بين أقل من ثلثان عددهم. وأوصت الدراسة بتحسين الوعى الصحى للطالبات فى هذا الموضوع باستخدام أساليب تعليمية مناسبة. كما أوصت بمزيد من الدر اسات العلمية الضرورية على مدارس و مناطق أخرى فى مصر فيما

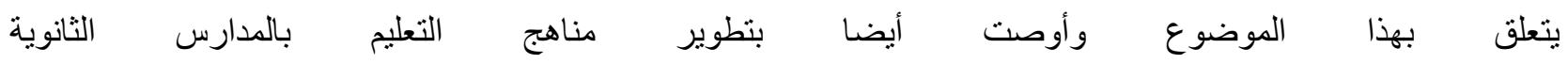
للتمريض.

الكلمات المرشدة :طالبات التمريض، التدخلات الصحية الوقائية، ممارسات الرعاية الذاتية، عدوى المسالك البولية 